RESEARCH ARTICLE

\title{
Isolation of raw starch hydrolysing fungi and purification of a-amylase from Geotrichum candidum CMSS06
}

\author{
S.N.T. De Silva, D.P.S.T.G. Attanayaka*, S.F. Nirosha and A.M.W.S. Aththanayaka \\ Department of Biotechnology, Faculty of Agriculture and Plantation Management, Wayamba University of Sri Lanka, Makandura, Gonawila (NWP)
}

Revised: 01 September 2008; Accepted: 17 October 2008

\begin{abstract}
Three starch degrading fungal species were isolated by exposing raw cassava and potato substrates to air and soil solutions. These three fungi were identified as Aspergillus spp., Mucor spp. and Geotrichum candidum by slide culture method. The optimum culture conditions for the production of extracellular $\alpha$-amylase from these three species were determined by measuring the $\alpha$-amylase activity, protein content and the $\mathrm{pH}$ of the culture media at $12 \mathrm{~h}$ intervals.

The highest raw starch hydrolysing $\alpha$-amylase activity $(6540 \mathrm{mU} / \mathrm{mL})$ was shown by the species G.candidum $72 \mathrm{~h}$ after incubation. The culture supernatant containing the enzyme activity was concentrated by $50 \%$ ammonium sulphate precipitation and two peaks were identified to contain the high $\alpha$-amylase activity following Dowex-cation exchange column chromatography. The two fractions collected from these two activity peaks had the specific activity of $136.3 \mathrm{mU} / \mathrm{mL}$ and $394.7 \mathrm{mU} / \mathrm{ml}$ for hydrolysing raw starch (RSHI) and soluble starch (SSI) respectively. The purification fold and recovery of the enzyme were 3.5 and 2 in RSHI and 11.2 and 10.9 in SSI. Further the maximum activity of the enzyme in RSHI fraction was detected at $40^{\circ} \mathrm{C}$ and $\mathrm{pH} 7$.
\end{abstract}

Keywords: Cassava, fungi, Geotrichum candidum, raw starch, $\alpha$-amylase

\section{INTRODUCTION}

Amylases are an important group of enzymes used in starch based industries. They digest glycosidic linkages in starch to give rise to diverse products including dextrin, and progressively smaller polymers composed of glucose units $^{1}$. $\alpha$-amylases $(\alpha-1,4$-D-glucan glucanohydrolases, EC 3.2.1.1) which are endogluconases, act upon polymeric molecules of carbohydrates at internal $\alpha-1-4$ glucan bonds in polysaccharides containing three or more $\alpha-1-4$ linkages which results in a mixture of maltose and glucose $e^{2}$.
In the face of the rising fossil fuel prices, starch derived energy has now become the global focus of attention. In spite of the growing concern on food security, variety of agricultural products are now being used as renewable energy sources. Amylase conversion of raw and soluble starch into energy and other related products will be a superior alternative to the conventionally used acid hydrolysis-based methods in terms of energy utilisation and process simplicity ${ }^{3,4,5}$.

$\alpha$-amylases are universally distributed in all organisms. The enzymes from fungal, bacterial and yeast sources have dominated applications in industrial sector. Extracellular raw-starch digesting amylases from Aspergillus spp. have been found important in application of bioconversion of starch and starch-based substrates ${ }^{3,5}$. However, to date, only few microorganisms have been reported to possess ability to produce raw starch degrading $\alpha$-amylases ${ }^{5,6,7}$.

This paper reports the results of a study on identification and isolation of fungal species, having extra-cellular $\alpha$-amylase activity on raw cassava starch and also the purification and characterisation of $\alpha$-amylases produced from such species with the long term objective of commercial utilisation of this enzyme.

\section{METHODS AND MATERIALS}

Isolation of $\alpha$-amylase producing fungi: Sliced and macerated cassava and potato, kept separately in Petri dishes were exposed to air and soil solutions at room temperature for the initial isolation of the fungi. Soil solutions used for inoculation were prepared by mixing approximately $5 \mathrm{~g}$ of top soil samples collected from different locations of the Makandura premises of the 
Wayamba University of Sri Lanka with $100 \mathrm{~mL}$ of distilled water. After the sedimentation of the large particles, 5 drops of the soil suspension were applied to the sliced material. For the macerated material, $1 \mathrm{~mL}$ of the soil suspension was applied. The isolation of amylolytic fungi grown on raw cassava and potato were done by selectively transferring the fungal colonies to the Potato Dextrose Agar (PDA) medium until pure cultures of the fungi were obtained. Two day old fungal colonies with different morphological characters were identified by examining their sporulating structures under the microscope by slide culture technique ${ }^{7}$. Purified cultures were identified to the species level at the Department of Botany, University of Kelaniya and the National Plant Quarantine Centre, Department of Agriculture. Pure cultures were maintained by sub-culturing monthly, on PDA slants.

$\alpha$-amylase assay: $\alpha$-amylase activity on raw starch and soluble starch was assayed by the method described by Henry et al ${ }^{8}$. Raw starch flour was prepared from cassava in the laboratory following the method described by Jansz et al ${ }^{9}$. Soluble potato starch and raw cassava starch in $0.1 \mathrm{M}$ phosphate buffer $(\mathrm{pH} 7)$ were used as substrates for enzyme assay. One unit of amylase was defined as the amount of enzyme, which liberates $1 \mathrm{mg}$ of reducing sugar per min under the assay conditions.

Preparation of glucose standard curve: Standard glucose curve was plotted using working glucose concentrations of $1 \mathrm{mg} / \mathrm{mL}, 2 \mathrm{mg} / \mathrm{mL}, 3 \mathrm{mg} / \mathrm{mL}, 4 \mathrm{mg} / \mathrm{mL}$ and $5 \mathrm{mg} / \mathrm{mL}^{8}$. Amount of reducing sugar liberated by the enzyme was determined with respect to the concentration of standard glucose.

Assay of protein: Protein content was determined by measuring the absorbance at $280 \mathrm{~nm}$ as compared to a standard curve prepared using Bovine Serum Albumin (BSA) protein dilution series.

Optimizing culture conditions for $\alpha$-amylase secretion: Eight cultures from each of the isolated fungi species were grown in Erlenmeyer flasks containing $50 \mathrm{~mL}$ sterilized fermentation medium $(1.5 \%$ soluble starch, $0.2 \%$ yeast extract, $0.01 \% \mathrm{MgSO}_{4}, 0.01 \% \mathrm{CaCl}_{2}, 0.26 \%$ $\mathrm{KH}_{2} \mathrm{PO}_{4}, \mathrm{pH} 4.0$ ) at $32^{\circ} \mathrm{C}$ in a rotary shaker at $100 \mathrm{rpm}$ for $96 \mathrm{~h}$. The $\alpha$-amylase activity, $\mathrm{pH}$ and the protein content of the culture supernatant of each of the fungal species were measured by sampling a single culture from each of the fungal species at $12 \mathrm{~h}$ intervals. Uninoculated cultures incubated at the same conditions were used as the reagent blank.

Extraction and purification of $\alpha$-amylase: Fungal species giving the highest enzyme activity on raw starch were selected and grown in $250 \mathrm{~mL}$ fermentation medium for $72 \mathrm{~h}$ under the same conditions given above. The supernatant was collected and the protein content, total $\alpha$-amylase activity on both raw and soluble starch were assayed. The proteins in the supernatant were concentrated by $50 \% \quad\left(\mathrm{NH}_{4}\right)_{2} \mathrm{SO}_{4}$ saturation and the redissolved precipitate after dialysis was assayed for the enzyme activity and protein content.

Ion-exchange chromatography: The enzyme was further purified by cation exchange chromatography using Dowex basic cation exchange matrix. The $\left(\mathrm{NH}_{4}\right)_{2} \mathrm{SO}_{4}$ fractionated samples were applied to the column at the rate of $1 \mathrm{~mL} / \mathrm{min}$. The column was eluted with $20 \mathrm{~mL}$ of phosphate buffer ( $\mathrm{pH} \mathrm{7)}$ with increasing ionic strength (0.05M, 0.06M, 0.08M, 0.1M, 0.12M, 0.14M, 0.16M, $0.18 \mathrm{M}, 0.2 \mathrm{M}$ and $0.2 \mathrm{M}+15 \% \mathrm{NaCl}$ ). Two milliliter fractions were collected manually. For each fraction the absorbance at $280 \mathrm{~nm}$ and $\alpha$-amylase activity on both raw and soluble starch were determined. The fractions giving higher enzyme activity peaks were pooled and the protein content and total $\alpha$-amylase activity on both raw and soluble starch were measured.

End-product analysis: Fifty milliliters of the culture medium ( $1.5 \%$ soluble starch, $0.2 \%$ yeast extract, $0.01 \%$ $\left.\mathrm{MgSO}_{4}, 0.01 \% \mathrm{CaCl}_{2}, 0.26 \% \mathrm{KH}_{2} \mathrm{PO}_{4}, \mathrm{pH} 4.0\right)$ was inoculated with G. candidum and incubated at $32^{\circ} \mathrm{C}$ in a rotary shaker at $100 \mathrm{rpm}$ for $72 \mathrm{~h}$. Iodine test was done to confirm the presence or absence of starch by taking $1 \mathrm{ml}$ samples at $12 \mathrm{~h}$ intervals.

\section{RESULTS}

\section{Identification of fungal species}

Three fungal species with different morphological characters were isolated from the culture media exposed to air and soil suspension. They were designated as PSA06 (Potato Sliced Air exposed, Figure 1a), PMSS06 (Potato Macerated Soil Solution exposed, Figure 1b) and CMSS06 (Cassava Macerated Soil Solution exposed, Figure 1c).

Under light microscope, PSA06 and PMSS06 had filamentous, branched and septate hyphae and long delicate sporangiophores. Based on the sporulating structure and colour of the spores of these two species, PSA06 was identified as Mucor spp. and PMSS06 as Aspergillus spp. (Figures 2a \& 2b). Species CMSS06 under light microscope clearly showed conidia (arthrospores) with variable width, length and cell wall structure. Slightly convex arthrospores round off to form chain of globes to sub-globes could be observed. 


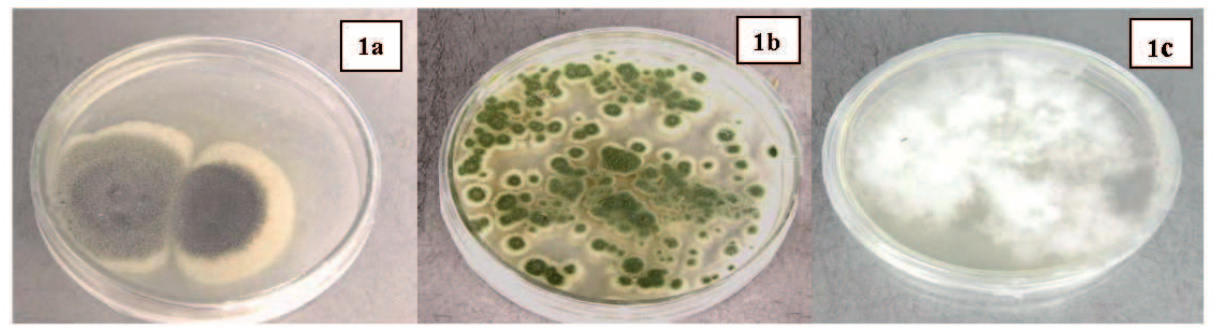

Figure 1: Morphological characters of isolated fungal colonies PSA06 (1a), PMSS06 (1b) and CMSS 06 (1c)

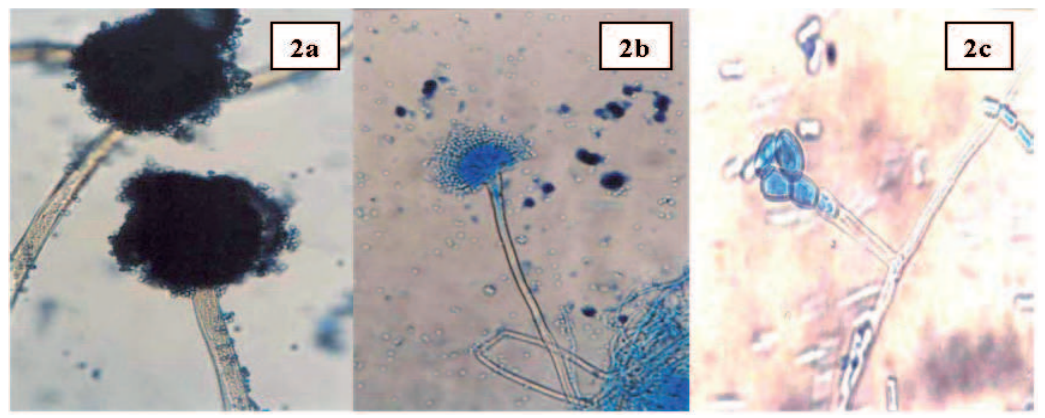

Figure 2: Structural features of isolated fungal species PSA06 (2a), PMSS06 (2b) and CMSS06 (2c) under light microscope (magnification 10 x 40)

Colonies were white and yeast-like but later produced white cottony aerial mycelium. Based on the structure and colour of the spores this fungal species CMSS06 was identified as G. candidum (Figure 2c).

\section{Optimum culture conditions for extracellular $\alpha$-amylase production}

The culture supernatant of Mucor spp. showed maximum activity of $5232.6 \mathrm{mU} / \mathrm{mL}$ and $3853.4 \mathrm{mU} / \mathrm{mL}$ for raw and soluble starch respectively at $84 \mathrm{~h}$ incubation period. However, the protein content at $84 \mathrm{~h}$ is comparatively low indicating the recovery of protein will be poor at this stage. $\mathrm{pH}$ of the culture supernatant dropped from 4.0 to 3.04 (Figure 3).

The culture supernatant of Aspergillus spp. showed maximum activity of $1233.5 \mathrm{mU} / \mathrm{mL}$ for raw starch at $96 \mathrm{~h}$ and $1116.6 \mathrm{mU} / \mathrm{mL}$ for soluble starch after $84 \mathrm{~h}$. $\mathrm{pH}$ of the medium dropped from 4 to 3.89 during the incubation period (Figure 4).

G. candidum CMSS06 showed maximum activity of $6540 \mathrm{mU} / \mathrm{mL}$ for raw starch at $72 \mathrm{~h}$ incubation period. The activity of the culture supernatant for soluble starch at this stage was $5094.7 \mathrm{mU} / \mathrm{mL}$. The protein content was comparatively high at this stage according to the absorbance values observed at $280 \mathrm{~nm}$. $\mathrm{pH}$ of the culture supernatant has dropped from 4.0 to 3.46 (Figure 5).

\section{$\alpha$-amylase activity on culture supernatant}

Based on the results, $72 \mathrm{~h}$ old culture supernatant of G. candidum CMSS06 which gave the highest raw starch hydrolysing activity was selected for purification of $\alpha$-amylase.

$\alpha$-amylase activity of culture supernatant at $72 \mathrm{~h}$ was $89 \mathrm{mU} / \mathrm{mL}$ and $82 \mathrm{mU} / \mathrm{mL}$ for raw and soluble starch respectively. Total volume used for extraction was $150 \mathrm{~mL}$. Therefore, the total $\alpha$-amylase activity in the culture volume was $13350 \mathrm{mU} / \mathrm{mL}$ for raw starch and $12300 \mathrm{mU} / \mathrm{mL}$ for soluble starch. The total protein content was $351 \mathrm{mg}$.

\section{Ammonium Sulphate fractionation}

Earlier studies conducted on $\left(\mathrm{NH}_{4}\right)_{2} \mathrm{SO}_{4}$ fractionation of $\alpha$-amylase indicated that $0-50 \%$ saturated precipitate contained higher $\alpha$-amylase activity than $50-100 \%$ saturated precipitate ${ }^{10}$. Therefore, $72 \mathrm{~h}$ old culture supernatant was immediately brought up to $50 \%$ saturation. This precipitate was dissolved in a minimum amount of $0.01 \mathrm{M}$ phosphate buffer and dialysis was done against the same buffer to remove the salts from the purified protein. 


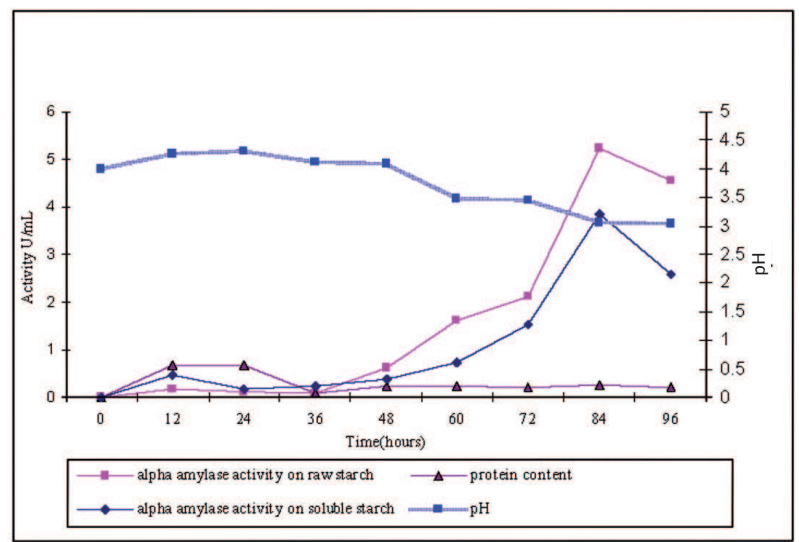

Figure 3: $\alpha$-amylase activity, $\mathrm{pH}$ and protein content of the culture supernatant of Mucor spp.

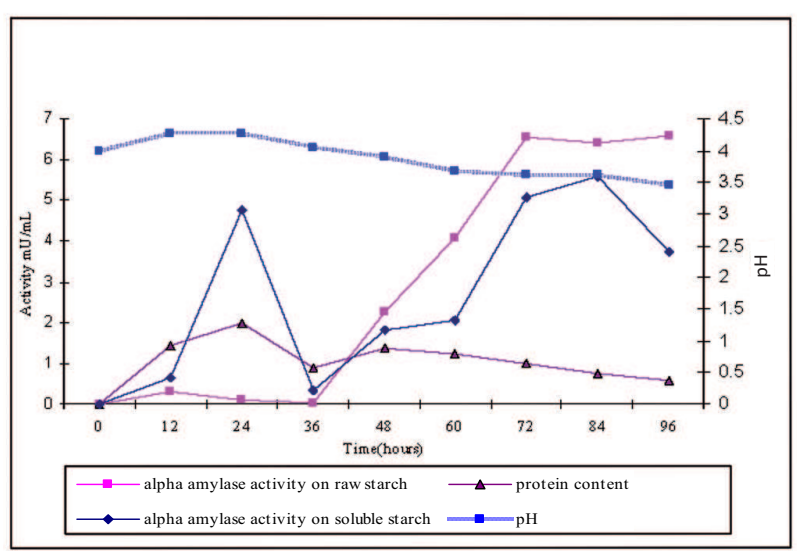

Figure 5: $\alpha$-amylase activity, $\mathrm{pH}$ and protein content of the culture supernatant of Geotrichum spp.

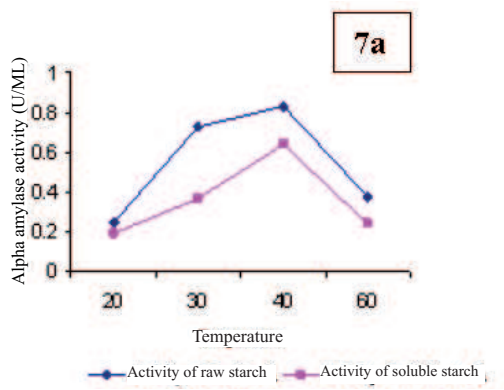

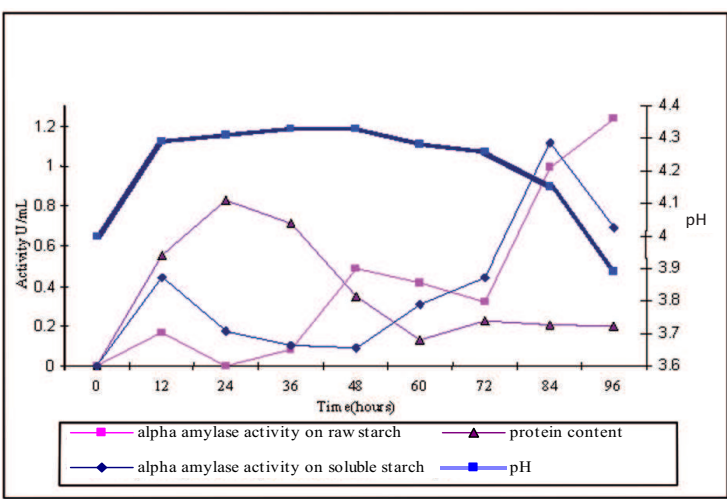

Figure 4: $\alpha$-amylase activity, $\mathrm{pH}$ and protein content of the culture supernatant of Aspergillus spp.

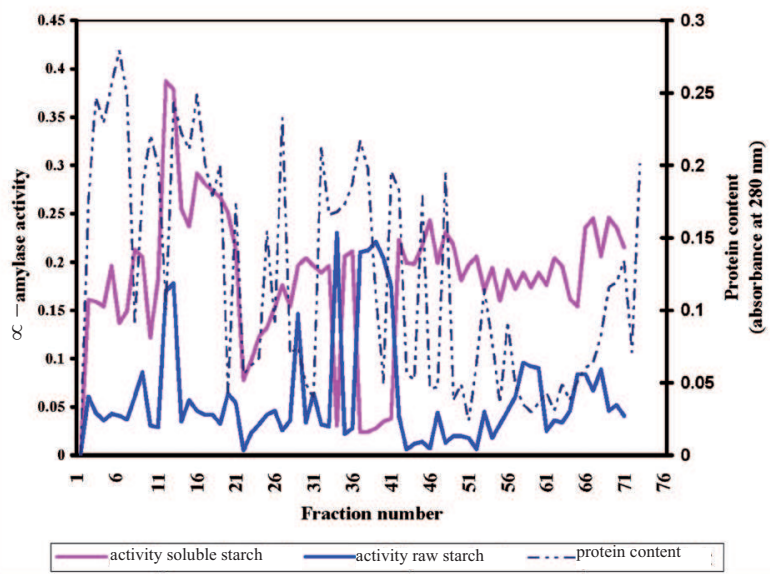

Figure 6: $\alpha$-amylase activity on raw and soluble starch and protein content of the collected fractions

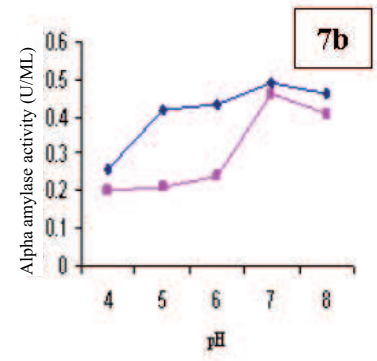

4.Activity of raw starch _LActivity of soluble starch

Figure 7: Effect of temperature (7a) and $\mathrm{pH}(7 \mathrm{~b})$ on $\alpha$-amylase activity from $G$. candidum CMSS06

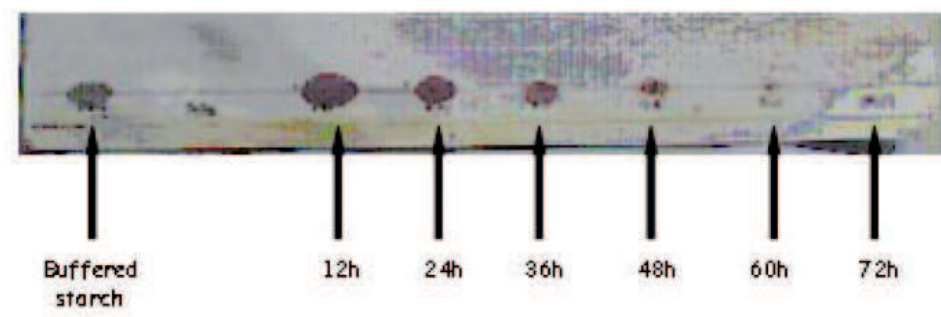

Figure 8: End product analysis done at $12 \mathrm{~h}$ intervals with iodine test 
Table 1: Details of the purification steps of raw starch hydrolysing $\alpha$-amylase from $G$. candidum CMSS06

\begin{tabular}{|c|c|c|c|c|c|c|c|c|c|c|}
\hline \multirow[t]{2}{*}{$\begin{array}{l}\text { Purification } \\
\text { step }\end{array}$} & \multirow[t]{2}{*}{$\begin{array}{l}\text { Volume } \\
(\mathrm{ml})\end{array}$} & \multirow{2}{*}{$\begin{array}{l}\text { Protein } \\
\text { content of } \\
\text { raw starch }\end{array}$} & \multicolumn{2}{|c|}{$\begin{array}{c}\text { Total } \\
\text { activity }(\mathrm{mU} / \mathrm{ml})\end{array}$} & \multicolumn{2}{|c|}{ Raw starch } & \multicolumn{2}{|c|}{ Soluble starch } & \multicolumn{2}{|c|}{ Purification fold } \\
\hline & & & $\begin{array}{l}\text { Raw } \\
\text { starch }\end{array}$ & $\begin{array}{l}\text { Soluble } \\
\text { starch }\end{array}$ & $\begin{array}{l}\text { Specific } \\
\text { activity } \\
(\mathrm{mU} / \mathrm{ml})\end{array}$ & $\begin{array}{c}\text { Recovery } \\
\%\end{array}$ & $\begin{array}{l}\text { Specific } \\
\text { activity } \\
(\mathrm{mU} / \mathrm{ml})\end{array}$ & $\begin{array}{c}\text { Recovery } \\
\%\end{array}$ & $\begin{array}{l}\text { Raw } \\
\text { starch }\end{array}$ & $\begin{array}{l}\text { Soluble } \\
\text { starch }\end{array}$ \\
\hline Culture medium & 150 & 327 & 13350 & 12300 & 40.8 & 100 & 35.0 & 100 & 1 & 1 \\
\hline $\begin{array}{l}50 \%\left(\mathrm{NH}_{4}\right)_{2} \mathrm{SO}_{4} \\
\text { Fractionation } \\
\text { Ion Exchange } \\
\text { Chromatography }\end{array}$ & 10 & 6.2 & 1200 & 1000 & 193.54 & 9 & 128.2 & 8.1 & 4.74 & 3.6 \\
\hline SS1 & 4.5 & 3.42 & - & 1350 & - & - & 394.7 & 10.9 & - & 11.2 \\
\hline RSH1 & 4.5 & 1.98 & 270 & - & 136.3 & 2 & - & - & 3.34 & - \\
\hline
\end{tabular}

Final volume obtained for $\left(\mathrm{NH}_{4}\right)_{2} \mathrm{SO}_{4}$ fractionated, dialysed sample was $10 \mathrm{~mL}$. $\alpha$-amylase activity of the sample was $120 \mathrm{mU} / \mathrm{mL}$ and $100 \mathrm{mU} / \mathrm{mL}$ for raw starch and soluble starch with the total activity of $1200 \mathrm{mU}$ and $1000 \mathrm{mU}$ respectively. Total protein content of this fraction was $7.8 \mathrm{mg}$.

\section{Ion exchange chromatography}

According to the values of $\alpha$-amylase assay, the highest $\alpha$-amylase activity for raw starch was given by the fractions from 37 to 40 . These fractions were eluted by 0.08M phosphate buffer ( $\mathrm{pH} 7.0$ ). They were pooled and labelled as RSH I. The highest activity on soluble starch given by the fractions from 11 to 19 were pooled and labelled as SS I which was eluted from $0.06 \mathrm{M}$ phosphate buffer ( $\mathrm{pH}$ 7.0). Most of the other proteins were eluted by $0.05 \mathrm{M}$ ionic strength according to the absorbance value observed at $280 \mathrm{~nm}$ (Figure 6).

Total volumes of the pooled fractions were $4.5 \mathrm{~mL}$. $\alpha$-amylase activity of RSH I and SS I were $60 \mathrm{mU} / \mathrm{mL}$ and $300 \mathrm{mU} / \mathrm{mL}$ with the total activity at $270 \mathrm{mU}$ and $1350 \mathrm{mU}$ for raw and soluble starch respectively.

Specific activity of the enzyme RSH 1 increased from $40.8 \mathrm{mU} / \mathrm{mg}$ to $136.3 \mathrm{mU} / \mathrm{mg}$ and purification fold was 3.34 (Table 1). The purified enzyme showed maximum activity at $\mathrm{pH} 7.0$ and $40^{\circ} \mathrm{C}$ (Figure 7).

\section{End-product analaysis}

Complete disappearance of starch was observed from the medium after $72 \mathrm{~h}$ incubation period (Figure 8 ).

\section{DISCUSSION}

Among the three fungal species isolated in this study, G. candidum CMSS06 gave the highest extracellular $\alpha$-amylase activity on both potato soluble starch and raw cassava starch. This species required lesser incubation period for maximum amylase activity when compared to the other two species studied (Mucor spp. and Aspergillus spp.). The fact that two enzyme activities specific to soluble starch and raw starch were obtained suggests the presence of two different forms of enzyme of the amylase family. This study confined only to the extracellular $\alpha$-amylase available in the culture supernatant. Low intracellular amylase activity in fungi species has been reported previously ${ }^{10}$.

Different $\alpha$-amylase activities were obtained in G. candidum CMSS06 cultures used for enzyme activity optimisation and enzyme extraction. This can be attributed to the variations in culture conditions such as initial inoculum concentrations which were not controlled in the present study.

Raw starch hydrolysing enzyme purified in this study had the specific activity of $136.6 \mathrm{mU} / \mathrm{mL}, 2 \%$ recovery and 3.34 purification fold.

The activity of the enzyme reported in this study was maximum at $40^{\circ} \mathrm{C}$ in agreement with earlier observations for other fungal starch digesting amylases ${ }^{3,11,12}$.Most raw starch digesting amylases are known to exhibit temperature optima between $40^{\circ} \mathrm{C}$ and $60^{\circ} \mathrm{C}$ and are remarkably stable against high temperatures ${ }^{13}$. Further studies should be carried out to study the stability of the crude enzyme identified in this study in different buffers, so that the temperature optimum may be further enhanced to make use of this enzyme for industrial uses at higher temperatures.

G. candidum CMSS06 after $72 \mathrm{~h}$ incubation with starch has shown complete disappearance of starch from the medium indicating its ability to convert starch into 
alpha limit dextrins. A similar study conducted in Nigeria using Aspergillus niger AM07 have shown the capacity to hydrolyse raw starch to sugars with higher conversion efficiency ${ }^{11}$.

G. candidum has been used as a starter culture for protection of barley in malts ${ }^{14}$ and for biotreatment of raw wastewaters, especially in starch processing ${ }^{15}$ and distillary wastewater effluent ${ }^{16}$. Its ability to remove nitrogen from the effluent is significant ${ }^{17}$, indicating the possibility of utilisation of agroindustrial effluents as a component of a low cost medium for $\alpha$-amylase production using G. candidum .

Appropriate combinations of amylolytic enzymes completely depolymerise starch to glucose. Detection and purification of raw starch hydrolysing enzyme in G. candidum CMSS06 species isolated in this study therefore shows the potential to be used in bioconversion of raw starch to low molecular weight sugars for alcoholic fermentation contributing to the global search for production of renewable energy resources.

\section{Acknowledgement}

The authors wish to acknowledge the advice given by Dr S.D.P. Kannangara, Department of Botany, University of Kelaniya, Dr D.B.Kelaniyangoda, Department of Horticulture and Landscape Gardening, Wayamba University of Sri Lanka and the staff of the National Plant Quarantine Center, Department of Agriculture for their assistance in identification of the fungi. Assistance provided by Mr. H.P.R.N. Pathirathna, Department of Biotechnology, Wayamba University of Sri Lanka is also acknowledged.

\section{References}

1. Windish W.W. \& Mhatre N.S. (1965). Microbial amylases. Advances in Applied Microbiology 7: 273-304.

2. Karkalas C. \& John S.P. (1985). An improved enzymatic method for the determination of native and modified starch. Journal of the Science of Food and Agriculture 36(10): 1019.

3. Fogarty W.M. (1983). Microbial amylases. In: Microbial Enzymes and Biotechnology (Ed. W.M. Fogarty) pp. 1-92. Applied Science Publishers, London, UK.

4. Achi O.K. \& Njoku-Obi A.N.U. (1992). Production of raw starch saccharification amylase by Bacillus alvei grown on different agricultural substrates. World Journal of Microbiology and Biotechnology 8(2): 206-207.
5. Okolo B.N., Ezeogu L.I. \& Mba C.I. (1995). Production of raw starch digesting amylase by Aspergillus niger grown on native starch sources. Journal of the Science of Food and Agriculture 69: 109-115.

6. Abe J., Bergmann F.W., Obeta K. \& Hizukuri S. (1988). Production of the raw starch digesting amylase of Aspergillus spp. K-27. Applied Microbiology and Biotechnology 27: 447- 450.

7. Radley J.A. (1953). Starch and its Derivatives. Vol.1. $3^{\text {rd }}$ Edition. pp. 369-401. John Wiley and Sons, New York, USA.

8. Henry R.J. \& Chiamori N. (1960). Study of the saccharogenic method for the determination of serum and urine amylase. Clinical Chemistry 5: 434.

9. Jansz E.R., Pierie N., Jeyaraj E.E. \& Abeyratne D.J. (1976). A process for improved manioc chips and flour. In: Industrial Microbiology Section-Annual Report of the Ceylon Institute of Scientific and Industrial Research $3^{\text {rd }}$ Edition. pp. 3-5. Industrial Technology Institute, Colombo.

10. De Silva S.N.T. (1997). Purification and characterization of raw starch hydrolysing $\alpha$-amylase from Aspergillus spp. M.Sc Thesis. Faculty of Medicine, University of Colombo, Colombo.

11. Omemu A.M., Akpan I., Bankole M.O. \& Teniola O.D. (2004). Hydrolysis of raw tuber starches by amylase of Aspergillus niger AM07 isolated from the soil. African Journal of Biotechnology 4(10): 19-25.

12. Okolo B.N., Ire F.S., Ezeogu L.I., Anyanwu C.U. \& Odibo F.J.C. (2000). Purification and some properties of a noval starch digesting amylase from Aspergillus carbonarius. Journal of the Science of Food and Agriculture 81(3): 329-336.

13. Forgarty W.M. \& Kelly C.T. (1979). Developments in microbial extracellular enzymes. In: Topics in Enzyme and Fermentation Biotechnology. Vol. 3 (Ed A.Wiseman). pp. 45-108. Applied Science Publishers, London, UK.

14. Foszczyńska B., Dziuba E. \& Stempniewicz R. (2004). The use of Geotrichum candidum starter culture for protection of barley and its influence on biotechnological qualities of malts. Electronic Journal of Polish Agricultural Universities 7(2): 4.

15. Jin B., van Leeuwen J., Yu Q. \& Patel B. (1999). Screening and selection of microfungi for microbial biomass protein production and water reclamation from starch processing wastewater. Journal of Chemical Technology and Biotechnology 74(7): 106-110.

16. Kida K., Morimura S., Abe N. \& Sonoda Y. (1995). Biological treatment of Shochu distillery wastewater. Process Biochemistry 30(2): 125-132.

17. Lacina C., Germain G. \& Spiros A.N. (2003). Utilisation of fungi for biological treatment of water. African Journal of Biotechnology 2(12): 620-630. 